\title{
Sludge concentration dynamic distribution and its impact on the performance of UNITANK
}

\author{
ZHANG Fa-gen ${ }^{1}$, LIU Jun-xin ${ }^{1, *}$, SUI Jun ${ }^{2}$ \\ 1. Reseurch Center for Eco-Environmental Sciences, Chinese Academy of Sciences, Beijing 100085, China. E-mail: Dustinzh@263.net \\ 2. Guangzhou Municipal Engineering Design and Research Institute, Guangzhou 510060, China
}

Received 3 March 2006; revised 11 May 2006; accepted 29 May 2006

\begin{abstract}
UNITANK is a biological wastewater treatment process that combines the advantages of traditional activated sludge process and sequencing batch reactor, which is divided into Tank A, B and C. In this study, the sludge distribution and its impact on performance of UNITANK were carried out in Liede Wastewater Plant (WWTP) of Guangzhou, China. Results showed that there was a strong affiliation between Tank A and B of the system in sludge concentration distribution. The initial sludge concentration in Tank A could present the sludge distribution of the whole system. The sludge distribution was mainly influenced by hydraulic condition. Unsteady sludge distribution had an impact on variations of substrates in reactors, especially in decisive reactor, and this could lead to failure of system. Settler could partially remove substrates such as COD and $\mathrm{NO}_{3}-\mathrm{N}$, but there was adventure of sludge deterioration. The rational initial sludge concentration in Tank A should be 4000-6000 mg/L MLSS.
\end{abstract}

Key words: L NITANK; sludge concentration; dynamic distribution; in-process study

\section{Introduction}

UNITANF is a biological wastewater treatment process that cor ibines the advantages of traditional activated sludge process and sequencing batch reactor (SBR). It is one rectangular reactor which is divided into three tanks, namedl as Tank A, B and C (Fig.1). The volumes of the three tanks are same and each tank is equipped with aeration and agitation systems. The process works according to a cyclic operation, of which Tank B works as reactor or ly, Tank $\mathrm{A}$ and $\mathrm{C}$ as either reactor or settler. The three tanks are connected with each other by pipe from bottom or via perforated wall. The wastewater is fed to Tank $A, B$ and $C$ alternatively and the cleaned water is discharged from Tank $\mathrm{C}$ or $\mathrm{A}$. There are no primary settler and sludge $r \in$ turn facilities.

UNITANK is commonly considered as modified SBR. However, it is quite different from SBR in configuration and hydrauli: condition because both influent and effluent are continuous. In a sense, it is more similar to a normal multi-re tetor process, such as A/O or UCT, but no sludge or mixed liquor returns. UNITANK is not special in configura ion and its biological processes seem no difference fr $m$ usual biological treatment mechanisms, such as degradation of organic carbon, transformation of nitrogen ind removal of phosphorus (Barker et al,, 1997; Brdjar ovic et al., 2000; Henze et al., 1987, 1995, 1999). The particular advantages of UNITANK include

Project supported by the National Natural Science Foundation of China (No. 50238050) Corresponding author. E-mail: jxliu@rcees.ac.cn. construction-compact, space-saving, cost-effective, flexible operation and easy to maintenance. Alternate control can perform a cycle of the anaerobic, anoxic, aerobic and settling conditions in one tank to remove organic substrate and enhance biological nutrient removal.

Since the running scheme is flexible, it is difficult to analyze its performance. UNITANK, strictly saying, is not a steadily running system because sludge concentrations in all tanks, hydraulic condition and effluent quality are unsteady. How to estimate its characteristics is still unsure. The conclusions from lab-scale or pilot-scale experiments do not always work well in full-scale plant since they are quite different. Additionally, little attention has been given to UNITANK performance so the in-process study is necessary and useful to mend UNITANK. Since no sludge returns into the UNITANK reactors, the sludge distribution will be different in Tank A, B and C, and changes with operation time. This sludge distribution will influence the performance of UNITANK. Therefore, the sludge distribution in the tanks and its impact on UNITANK performance were investigated in this paper.

UNITANK process is used in Liede Wastewater Treatment Plant (WWTP) of Guangzhou City and the study was carried out in this plant in one year of 2004. The study was first focused on the sludge distribution in the tanks and then on the in-process performance of UNITANK.

\section{Materials and method}

\subsection{Full-scale UNITANK process}

About $260000 \mathrm{~m}^{3} / \mathrm{d}$ of wastewater was treated by the 


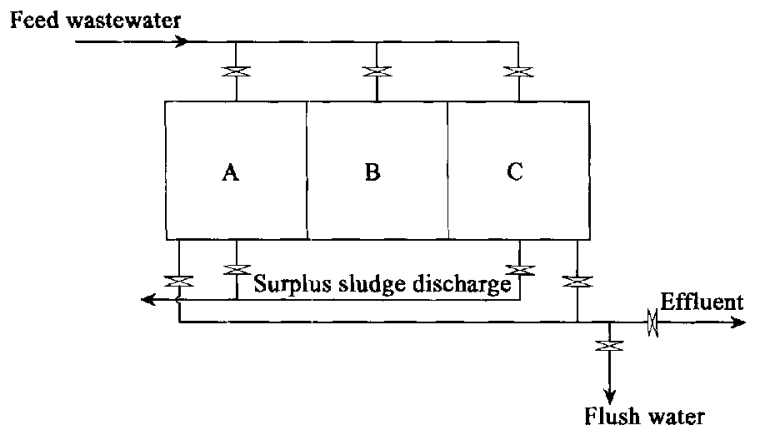

Fig. 1 Configuration of conventional UNITANK.

UNITANK process in Liede WWTP. The layout of UNITANK process is shown in Fig.2.

In this UNITANK process, there are eight independent UNITANK units, which form four groups (group 1-4), and each group includes two parallel UNITANK units (Fig.3). The inclined-tube systems are equipped in Tank $A$ and $C$ of each unit (Fig.1) to increase the efficiency of solidliquor separation. Each unit has a total effective volume of about $14000 \mathrm{~m}^{3}$. The raw wastewater is lifted by pump with a mean flow rate of $1365 \mathrm{~m}^{3} / \mathrm{h}$ into each unit and the corresponding hydraulic retention time (HRT) is about 10 h.

\subsection{Analytical methods}

MLSS, MLVSS, SS, COD, BOD $5, \mathrm{NH}_{3}-\mathrm{N}, \mathrm{NO}_{3}-\mathrm{N}$ and $\mathrm{PO}_{4}-\mathrm{P}$ were determined according to the standard methods (APHA, 1995). Fractions of COD, namely readily degradable-soluble $\operatorname{COD}\left(\mathrm{S}_{\mathrm{S}}\right)$, inert-soluble $\operatorname{COD}\left(\mathrm{S}_{1}\right)$, slowly degradable-particulate $\operatorname{COD}\left(\mathrm{X}_{\mathrm{S}}\right)$ and inert-particulate $\operatorname{COD}\left(\mathrm{X}_{\mathrm{I}}\right)$ were determined in other ways (Henze et al., 1995, 1999; Roelveld and van Loosdrecht, 2002).

MLSS was used as sludge concentration index. COD, $\mathrm{NH}_{3}-\mathrm{N}, \mathrm{NO}_{3}-\mathrm{N}$ and $\mathrm{PO}_{4}-\mathrm{P}$ were chosen as substrate indices.

\subsection{Operation conditions}

\subsubsection{Raw wastewater}

The raw wastewater came from the municipal sewer and entered the UNITANK process via a grit chamber (Fig.2). Its characters are shown in Fig. 4.

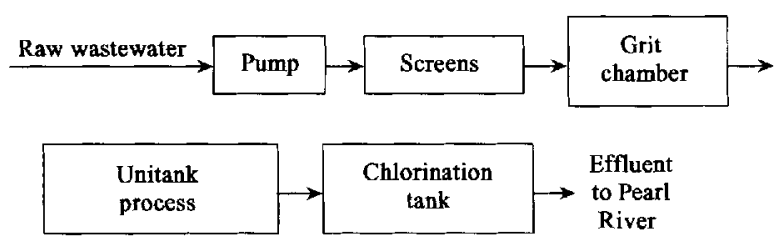

Fig. 2 Layout of wastewater treatment process in Liede WWTP.

\begin{tabular}{|c|c|c|c|c|c|}
\hline A & B & C & $\mathbf{A}$ & B & C \\
\hline $\mathbf{A}$ & B & C & A & $B$ & C \\
\hline \multicolumn{6}{|c|}{ Group 1} \\
\hline A & B & C & A & $\mathrm{B}$ & C \\
\hline $\mathbf{A}$ & B & $\mathrm{C}$ & A & B & C \\
\hline \multicolumn{3}{|c|}{ Group 2} & \multicolumn{3}{|c|}{ Group 4} \\
\hline
\end{tabular}

Fig. 3 Layout of UNITANK process in Liede WWTP.

With low substrate concentrations, the raw wastewater was typical in Southern China. BOD $_{5}$ was between 50 and $120 \mathrm{mg} / \mathrm{L}$ with average of $84 \mathrm{mg} / \mathrm{L}$. COD was between 90 and $200 \mathrm{mg} / \mathrm{L}$ with average of $150 \mathrm{mg} / \mathrm{L}$, of which $\mathrm{S}_{\mathrm{S}}$, $\mathrm{S}_{\mathrm{I}}, \mathrm{X}_{\mathrm{S}}$ and $\mathrm{X}_{\mathrm{I}}$ accounted for about $14 \%, 16 \%, 43 \%$ and $27 \%$, respectively. SS was between 80 and $160 \mathrm{mg} / \mathrm{L}$ with average of $104 \mathrm{mg} / \mathrm{L}$. $\mathrm{NH}_{3}-\mathrm{N}$ was between 10 and $40 \mathrm{mg} / \mathrm{L}$ with average of $22 \mathrm{mg} / \mathrm{L}$. TP was between 1.7 and 3.5 $\mathrm{mg} / \mathrm{L}$ with average of $2.6 \mathrm{mg} / \mathrm{L}$, of which $\mathrm{PO}_{4}-\mathrm{P}$ accounted for about $70 \%-90 \%$.

\subsubsection{Running and sampling scheme}

An operation cycle is composed of two half-cycles with same running schemes, in which the raw wastewater flows from Tank A to Tank C during the first half-cycle, and from Tank $\mathrm{C}$ to Tank A during the second. Therefore, only one half-cycle was researched in this study. This half-cycle scheme is shown in Table 1 and divided into four periods named as Period 1, 2, 3 and 4, respectively. In this scheme, Tank $A$ and $B$ worked as reactor, and Tank $C$ as settler.

Eight sampling points were chosen in each tank and samples from these eight points were mixed as an instantaneous sample.

The sampling scheme of Tank A and B for MLSS is shown in Table 2. No sample in Tank A was taken from

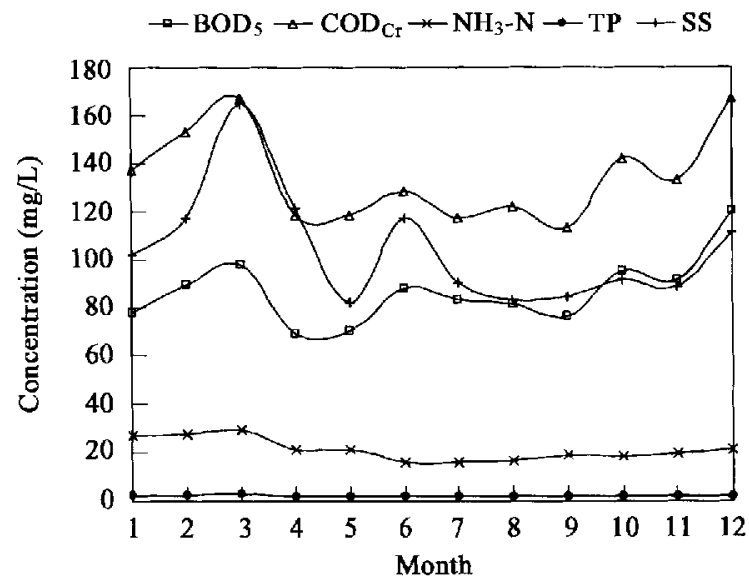

Fig. 4 Characters of raw wastewater in year 2004 .

Table 1 First half-cycle scheme of UNITANK in Liede WWTP

\begin{tabular}{lllll}
\hline Period & Start point & Period $1(60 \mathrm{~min})$ & Period $2(120 \mathrm{~min})$ & Period $3(30 \mathrm{~min})$ \\
\hline Tank A & Feed & Fecd/Aerobic & Feed/Anoxic/Anaerobic & Aerobic \\
Tank B & & Aerobic & Aerobic & Feed/Anoxic \\
Tank C & & Settling & Settling & Settling \\
\hline
\end{tabular}


Table 2 Sampling scheme for MISS in Tank A and B

\begin{tabular}{lllllllll}
\hline Series number & 1 & 2 & 3 & 4 & 5 & 6 & 7 & 8 \\
\hline Tank A (min) & 1 & 5 & 20 & 35 & 50 & 180 & 195 & 210 \\
Tank B (min) & 1 & 30 & 60 & 90 & 120 & 150 & 180 & 210 \\
\hline
\end{tabular}

the 60 th to 180 th min since inclined-tube system made the sample unrepresentative during anoxic or anaerobic period (Table 1).

Continuou ly changing sludge concentration would lead to variations in organic loads, oxygen concentration and efficiency of substrate removal. The effect of this change could be reflected by in-process study on variations of substrate. Tink B is decisive in whole UNITANK unit, so the variations of substrate in Tank B were studied. The substrates in effluent were also studied to analyze the efficiencies o: biological treatment and settling.

The sampling scheme for in-process study is shown in Table 3. During this half-cycle, the raw wastewater quality was considered unchangeable. The samples from Tank A (not shown in Table 3), B and C represented the raw wastewater, variations of substrate and effluent, respectively.

Table 3 Sampling scheme for water quality in Tank C and Tank B

\begin{tabular}{llllllll}
\hline Series number & 1 & 2 & 3 & 4 & 5 & 6 & 7 \\
\hline Tank C (min) & 1 & 30 & 60 & 120 & 180 & 210 & \\
Tank B (min) & 1 & 30 & 60 & 120 & 180 & 210 & 240 \\
\hline
\end{tabular}

\subsubsection{Other ronditions}

During the whole study, the running scheme was un changed. Te mperature was between $13-27^{\circ} \mathrm{C}$. The raw wastewater $u$ as weak alkali with $\mathrm{pH}$ value of $7.2-7.5$. The controllable factors included soluble oxygen and initial sludge concentration in Tank A. During this experiment, the ratio of MLVSS and MLSS was almost stable.

\section{Results and discussion}

\subsection{Sludge distribution}

Figs.5a an $\downarrow 5 \mathrm{~b}$ show the MLSS distribution in Tank A and $B$, respe:tively. $S 1-S 7$ were the test results in seven half-cycles.

Since the raw wastewater entered Tank A and its mixed liquor flowed into Tank B, the MLSS in Tank A decreased continuously (Fig.5a). The higher the initial sludge concentration was, the more it reduced. The MLSS was $4000-13000 \mathrm{mg} / \mathrm{L}$ at the start and $3000-5000 \mathrm{mg} / \mathrm{L}$ in the end (Fig.5a). The reduction rate of MLSS was 4.8-38.1 $\mathrm{mg} /(\mathbf{L} \cdot \min )$.

The change of MLSS in Tank B was quite different from that in Tank A (Fig.5b). At the start, the MLSS was higher in Tank A than in Tank B so that the MLSS accumulation was greater than the MLSS loss in Tank B. As a result, the MLSS in Tank B ascended quickly in the former 90 min. Between $90-150 \mathrm{~min}$, the MLSS in Tank B began to descend because the MLSS in Tank A became lower and less MLSS entered Tank B. Between 150-180 min, the MLSS in Tank B descended more quickly since the MLSS became lower in Tank A than in Tank B. After 180 min, the MLSS in Tank B decreased much more quickly because no MLSS entered Tank B from Tank A, and the raw wastewater was fed into Tank $B$.

The test results from other UNITANK units showed that MLSS variations were similar to that in Figs. $5 a$ and 5 b.

Theoretically, the mass balance equation of MLSS in Tank A or B is given by Leslie et al. (1999):

$V \frac{\mathrm{d} C}{\mathrm{~d} t}=F C_{0}-F C+r V$

Where, $C$ is the MLSS in reactor $(\mathrm{mg} / \mathrm{L}) ; C_{0}$ is the MLSS of influent, equal to SS in raw wastewater into Tank A or MLSS from Tank A into Tank B $(\mathrm{mg} / \mathrm{L}) ; V$ is the effective volume of reactor $\left(\mathrm{m}^{3}\right) ; F$ is the flow rate $\left(\mathrm{m}^{3} / \mathrm{h}\right)$; $r$ is the reaction rate $(\mathrm{mg} /(\mathrm{L} \cdot \mathrm{h}))$.

The change of MLSS can be simulated according to Equation (1). Considering the raw wastewater quality stable and choosing S2 (Figs.5a and 5 b) as target, the changes of the measured and simulated MLSS in Tank A and $B$ are shown in Fig.6.

Evidently, the simulated results do not accord with the measured perfectly. From measured results and Equation (1), it can be concluded that the sludge distribution is influenced by not only HRT, initial sludge concentration,
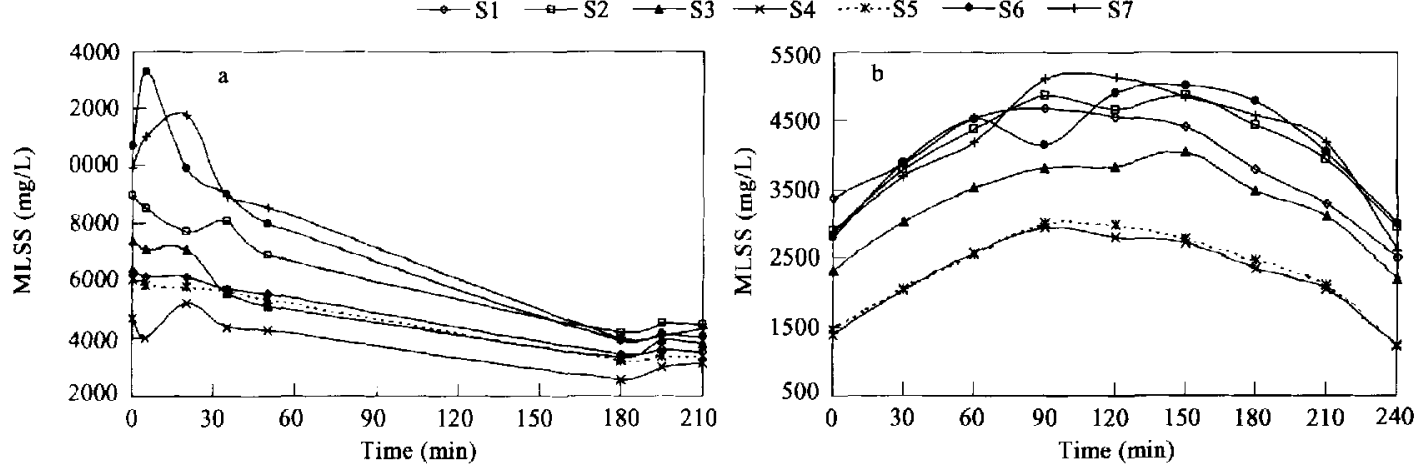

Fig. 5 MLSS change in Tank A (a) and Tank B (b) of UNITANK. 

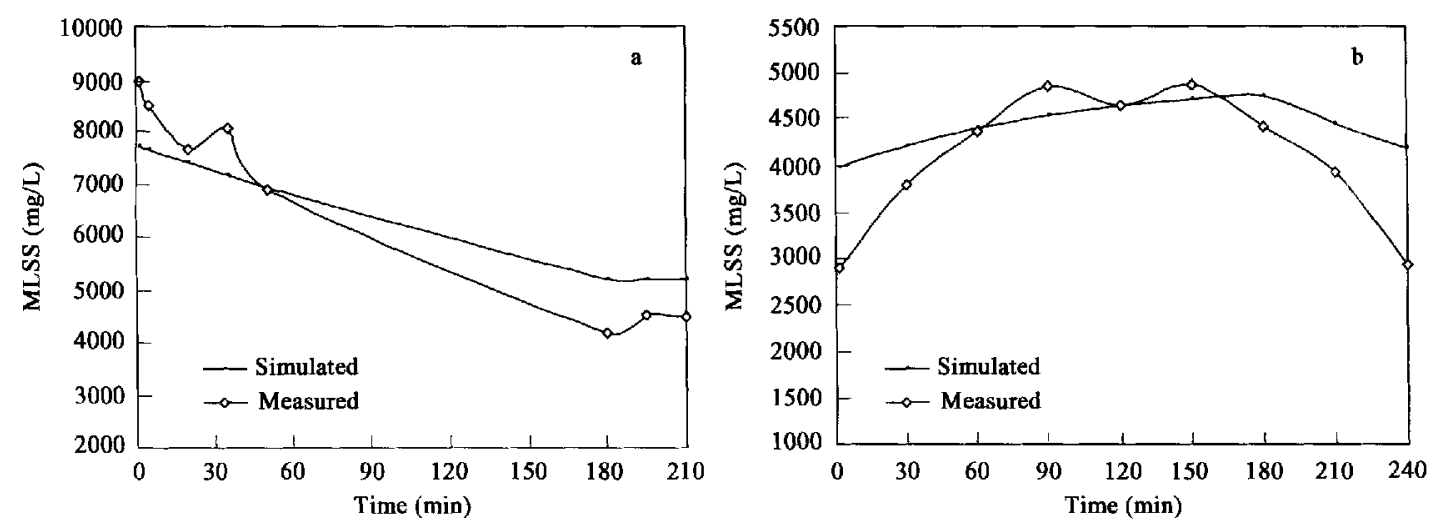

Fig. 6 Changes of measured and simulated MLSS in Tank A (a) and B (b).

sludge growth and discharge but the structure of reactor. For UNITANK, HRT plays the most remarkable role influencing the sludge distribution. It could be estimated that the sludge concentration in Tank A would be too low if the raw wastewater was fed to Tank A for a very long time, so did Tank B. Therefore, HRT and the half-cycle and feeding period should be well controlled.

\subsection{Evaluation of SRT in UNITANK}

Sludge retention time (SRT) plays an important role in BNR system (Yoshitaka, 1994; Peter, 1998; Ligero et al., 2001; Henze et al., 2002; Liss et al., 2002; Adeline et al., 2003; Clara et al., 2005). In general, it can be defined as Equation (2) (Leslie et al., 1999):

$\operatorname{SRT}(\mathrm{d})=\frac{M_{\mathrm{T}}}{M_{\mathrm{d}}}$

where, $M_{\mathrm{T}}$ is the total mass of sludge in system, and $M_{\mathrm{d}}$ is discharged mass of sludge everyday.

In most cases, intermittent sludge discharge is applied in UNITANK process. So specific calculating method of SRT for intermittent sludge discharge is introduced as:

$\operatorname{SRT}(\mathrm{d})=\frac{M_{\mathrm{T}} \times t}{M_{\mathrm{d}} \times 24}$

Where, $t$ is the time length of one half-cycle (h); 24 is $24 \mathrm{~h}$ of a day.

$M_{\mathrm{d}}$ is an easily-controlled parameter via batch pumping of sludge from settling area. $M_{\mathrm{T}}$ is a troublesome parameter because MLSS varies in both reactor and settler so that total mass can not be determined easily. To calculate $M_{\mathrm{T}}$, the relativity of MLSS between Tank A and B was investigated (Fig.7).

It is obvious that the MLSS in Tank B is corresponding to that in Tank A. In other words, the higher the initial MLSS in Tank A is, the higher the MLSS in Tank B is during the half-cycle. The initial MLSS of $S_{1}$ in Tank A was about $13000 \mathrm{mg} / \mathrm{L}$, the MLSS of S1 in Tank B increased from about $3000 \mathrm{mg} / \mathrm{L}$ of the initial to 5000 $\mathrm{mg} / \mathrm{L}$ of peak value. The initial MLSS of S2 in Tank A was about $7000 \mathrm{mg} / \mathrm{L}$, the MLSS of S2 in Tank B increased from about $2000 \mathrm{mg} / \mathrm{L}$ of the initial to $4000 \mathrm{mg} / \mathrm{L}$ of peak value. Furthermore, in Tank B, the final MLSS were basically same with the initial one. Results indicated that this phenomenon was similar before or after this half-cycle for a considerably long time if excess sludge discharge was rational. $M_{\mathrm{T}}$ could then be evaluated according to the nearest half-cycles. $M_{\mathrm{T}}$ can be divided into three parts: (1) sludge mass in Tank A (SMST); (2) sludge mass in Tank B (SMMT) and (3) sludge mass in Tank C (SMSA). $M_{\mathrm{T}}$ can be calculated by:

$M_{\mathrm{T}}=\mathrm{SMST}+\mathrm{SMMT}+\mathrm{SMSA}$

According to the running scheme (Table 1) and results in Fig.5a, MLSS in Tank A was stable after $180 \mathrm{~min}$ until the end. So the SMST and SMMT can be calculated by the effective volume of Tank A or B and corresponding MLSS concentration at the end of this half-cycle. SMSA can be made certain as the initial MLSS in Tank C at next halfcycle.

For UNITANK, the evaluation of SRT could be based on Equations (3) and (4). In this study, the real SRT was mean value of ten nearest half-cycles' SRTs of same unit.

As discussed above, a steadily running UNITANK process keeps strong affiliation between Tank A and Tank $B$ in sludge concentration. Given the initial MLSS in Tank A, the MLSS distributions in Tank A and B could be described. SRT could be easily-controlled if the online sensor and fuzzy monitor are used for manual control (Wong et al., 2005; Chang et al., 2003).

\subsection{In-process study on variations of substrate}

Only the initial sludge concentration in Tank A was tested since it could present the MLSS distribution basically.

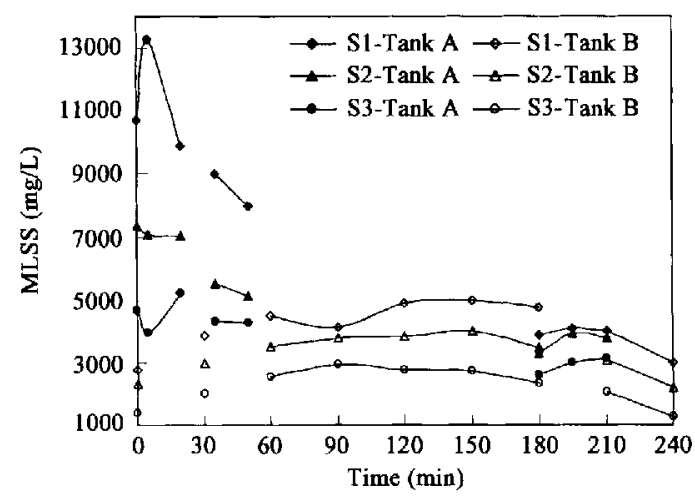

Fig. 7 MLSS relativity in UNITANK units. 
Influent quality was considered stable during the tested half-cycle.

\subsubsection{Variations of substrate in Tank B}

Part precondition data are shown in Table 4. Variations of $\mathrm{COD}, \mathrm{NH}_{3}-\mathrm{N}, \mathrm{NO}_{3}-\mathrm{N}$ and $\mathrm{PO}_{4}-\mathrm{P}$ are shown in Figs.8a, $8 \mathrm{~b}, 8 \mathrm{c}$, and $8 \mathrm{~d}$, respectively.

Generally speaking, except $\mathrm{PO}_{4}-\mathrm{P}$, the change trend of the rest was basically similar. This trend was accordant with that of MLSS in Tank B (Fig.5b). It could be explained by equation (Henze et al., 1987, 1995, 1999; Leslie et al., 1999):

$r=\mu_{\max } \frac{S}{K_{\mathrm{S}}+S} X$

Where, $r$ is the reaction rate $(g /(L \cdot d)) ; \mu_{\max }$ is the maximum specific growth rate $\left(\mathrm{d}^{-1}\right) ; K_{\mathrm{S}}$ is the half saturation coefficient $(\mathrm{mg} / \mathrm{L}) ; S$ is the substrate's concentration $(\mathrm{mg} / \mathrm{L})$ and $X$ is the sludge concentration $(\mathrm{g} / \mathrm{L})$.

It should be mentioned that most $\mathrm{NH}_{3}-\mathrm{N}$ had been transformed into $\mathrm{NO}_{3}-\mathrm{N}$ and the change trend of $\mathrm{NO}_{3}-\mathrm{N}$

Table 4 Partial precondition data for in-process study on Tank B

\begin{tabular}{llll}
\hline Scries code & $\mathrm{C} 1$ & $\mathrm{C} 2$ & $\mathrm{C} 3$ \\
\hline Initial sludge concentration in Tank A $(\mathrm{mg} / \mathrm{L})$ & 6959 & 6501 & 5801 \\
$\mathrm{SRT}(\mathrm{d})$ & $\approx 11$ & $\approx 8$ & $>20$ \\
$\mathrm{COD}$ of influent $(\mathrm{mg} / \mathrm{L})$ & 285 & 223 & 118 \\
$\mathrm{NH}_{3}-\mathrm{N}$ of influent $(\mathrm{mg} / \mathrm{L})$ & 27.4 & 28.3 & 22.8 \\
$\mathrm{NO}_{3}-\mathrm{N}$ of influent $(\mathrm{mg} / \mathrm{L})$ & 0 & 0.2 & 0 \\
$\mathrm{PO}_{4}-\mathrm{P}$ of influent $(\mathrm{mg} / \mathrm{L})$ & 2.9 & 2.2 & 1.8
\end{tabular}

$\mathrm{C} 1, \mathrm{C} 2$ and $\mathrm{C} 3$ are the test results in several half-cycles. was opposite to that of $\mathrm{NH}_{3}-\mathrm{N}$. So only the change trend of $\mathrm{NH}_{3}-\mathrm{N}$ needs be analyzed.

In the first $90 \mathrm{~min}, S$ was very high and $S /\left(K_{S}+S\right)$ changed little so that $r$ increased with $X$ ascended. As a result, the transformation of substrate speeded up and the $S$ went down. Between 90-150 min, $S$ was tended to be low and $S /\left(K_{\mathrm{S}}+S\right)$ began to decrease obviously. Although $X$ continued to ascend, $r$ decreased. So the transformation of substrate slowed down. Between $150-180 \mathrm{~min}, X$ began to descend but $r$ and $S$ were still low, leading to little change of $S$. After $180 \mathrm{~min}$, the raw wastewater was fed to Tank B and $X$ began to descend faster. On the other hand, the Tank $B$ tended to be anoxic, which influenced $r$ greatly. As a result, in Tank B, the entered $S$ surpassed the transformed $S$, leading to the accumulation of $S$. For example, for $\mathrm{NH}_{3}$ $\mathrm{N}$ of $\mathrm{C} 2$ (Fig.8b), $K_{\mathrm{S}}$ is about $1 \mathrm{mg} / \mathrm{L}$, changes of other parameters are shown in Table 5.

However, the transformation of substrate is so complex that Equation (5) could not describe it accurately. According to the observation, Equation (5) could explain the transformation of substrate rationally.

For $\mathrm{PO}_{4}$, its removal is accomplished mainly by two sequencing biological processes of anaerobic release and aerobic (anoxic) excess uptake and by process of chemical precipitation (Henze et al., 1995, 1999; Rieger et al., 2001). The efficiency of $\mathrm{PO}_{4}-\mathrm{P}$ removal is influenced by $\mathrm{SRT}$, influent quality, $\mathrm{COD} / \mathrm{PO}_{4}-\mathrm{P}$, oxygen, alkalinity and $\mathrm{NO}_{3}-\mathrm{N}$. The $\mathrm{PO}_{4}$ varied between $0.2-0.5 \mathrm{mg} / \mathrm{L}(\mathrm{C} 2$ and $\mathrm{C} 3$ in Fig.8d), which shows UNITANK process's potential to remove $\mathrm{PO}_{4}$ efficiently. Further study should be conducted

Table 5 Changes of parameters in Equation (5) for $\mathrm{NH}_{3}-\mathrm{N}$ of $\mathrm{C} 2$

\begin{tabular}{lllllllll}
\hline Time (min) & 1 & 30 & 60 & 90 & 120 & 150 & 240 \\
\hline$S$ & 6.6 & 4.6 & 2.2 & $\approx 1.5 *$ & 0.4 & $\approx 0.2 *$ & 0.1 & 1.8 \\
$X$ & 3.3 & 3.8 & 4.2 & 4.3 & 4.5 & 4.4 & 3.8 & 3.5 \\
$S /\left(K_{S}+S\right)$ & 0.87 & 0.82 & 0.69 & 0.60 & 0.29 & 0.17 & 0.09 & 0.64 \\
$r\left(\times \mu_{\max }\right)$ & 2.86 & 3.12 & 2.88 & 2.58 & 1.29 & 0.73 & 0.35 & $1.35 * *$ \\
\hline
\end{tabular}

*Fitted data according to plotted curve (Fig.8b); **the anaerobic (anoxic) $\mu_{\max }$ is about $60 \%$ of the aerobic $\mu_{\max }$
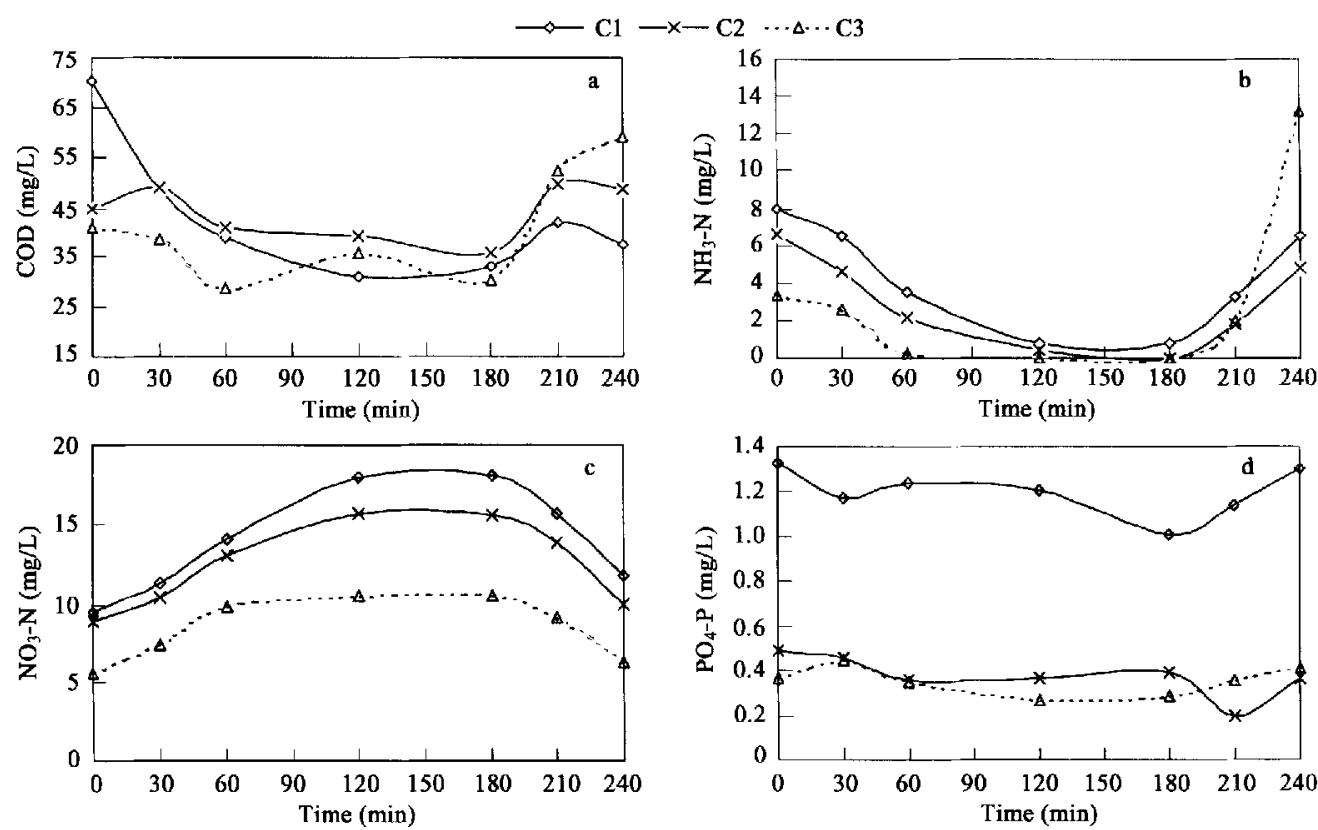

Fig. 8 Variation of $\mathrm{COD}(\mathrm{a}), \mathrm{NH}_{3}-\mathrm{N}(\mathrm{b}), \mathrm{NO}_{3}-\mathrm{N}$ (c) and $\mathrm{PO}_{4}-\mathrm{P}$ (d) in Tank $\mathrm{B}$. 
on $\mathrm{PO}_{4}$ remoral.

Period 3 and 4 (Table 1) are two transitional stages during which. the raw wastewater must be fed into Tank B. As discussed above, the anoxic and anaerobic conditions are not good for substrate removal. Therefore, the decisive tank should tiot be anoxic or anaerobic. The impact of sludge concentration on substrates removal is not obvious but long SRT helps to remove $\mathrm{NH}_{3}-\mathrm{N}$ (Table 4 and Fig. 8 b).

\subsubsection{Variations of substrate in effluent}

Table 6 shows part precondition data that were similar to that in Table 4. So the change trend of substrate in Tank B of this study should be accordant with that in Fig. $5 \mathrm{~b}$. Between 210-240 min, both Tank $A$ and $C$ worked as settler so no sample was taken. Variations of $\mathrm{COD}, \mathrm{NH}_{3}-$ $\mathrm{N}, \mathrm{NO}_{3}-\mathrm{N}$ and $\mathrm{PO}_{4}-\mathrm{P}$ are shown in Figs.9a, $9 \mathrm{~b}, 9 \mathrm{c}$ and $9 \mathrm{~d}$, respectively.

Table 6 Partial precondition data for in-process study on eflluent

\begin{tabular}{llll}
\hline Series code & $\mathrm{Cl}$ & $\mathrm{C} 2$ & $\mathrm{C} 3$ \\
\hline Initial concentrat on in Tank A $(\mathrm{mg} / \mathrm{L})$ & 6218 & 4708 & 5051 \\
$\mathrm{SRT}(\mathrm{d})$ & $\approx 12$ & $>20$ & $\approx 7$ \\
$\mathrm{COD}$ of influent $\mathrm{mg} / \mathrm{L})$ & 198 & 164 & 180 \\
$\mathrm{NH}_{3}-\mathrm{N}$ of influer $\mathrm{L}(\mathrm{mg} / \mathrm{L})$ & 26.7 & 17 & 23.6 \\
$\mathrm{NO}_{3}-\mathrm{N}$ of influen $\mathrm{l}(\mathrm{mg} / \mathrm{L})$ & 0 & 0 & 0 \\
$\mathrm{PO}_{4}-\mathrm{P}$ of influen! $(\mathrm{mg} / \mathrm{L})$ & 2.1 & 1.7 & 2.9 \\
\hline
\end{tabular}

$\mathrm{C} 1, \mathrm{C} 2$, and $\mathrm{C} 3$ a c the test results in several half-cycles.

Usually, the settler is considered simple solid-liquor separator where no bio-chemical reaction happened (Henze et al., 1987, 1995. 1999). Since intermittent sludge discharge is applied, there must be too much sludge accumulated in settler before it is discharged. As a result, the sludge possibly overflows into the effluent (Hasselblad et al., 1998). Furth rmore, the bio-chemical reactions, such as denitrificatior, could happen during settling (Kazmi et al., 2000: Siegrist et al., 1994).

Fig. 10 shows the performance characteristic of settler.
The parameter of solid removal efficiency is introduced to describe the settler's characteristic. The maximum, minimum and mean values of removal efficiency were $99.89 \%, 99.27 \%$ and $99.68 \%$, respectively. The results suggested that no obvious sludge overflowed and very few particulate substrates appeared in effluent. The sludge stayed in the settler for about $4 \mathrm{~h}$ before it was discharged. With addition and compaction of sludge, the sludge layer tended to be anoxic. The in situ measurements by sensor proved that the oxygen concentration in the sludge layer was approximately $0.1-0.8 \mathrm{mg} / \mathrm{L}$ and the denitrification would happened in this situation.

If the settler is considered simple solid-liquor separator, the change trend of substrate in effluent should be accordant with that in Tank B. Evidently, the change of substrate in effluent was not as sharp as that in Tank B. COD reached the lowest at about 120 min in Tank B (Fig.8a) but at about $30 \mathrm{~min}$ in the settler (Fig.9a). It indicated that the denitrifier consumed the biodegradable COD which was not degraded completely in Tank $\mathrm{B}$, leading to COD reduction. At the same time, $\mathrm{NO}_{3}-\mathrm{N}$ was transformed so it did not increase until $30 \mathrm{~min}$ (Fig.9c). Insufficient biodegradable $\mathrm{COD}$ made no further $\mathrm{NO}_{3}-\mathrm{N}$ reduction since about $7.7 \mathrm{~g}$ COD is needed for transforming $1 \mathrm{~g}$ $\mathrm{NO}_{3}-\mathrm{N}$ (Siegrist et al., 1994). For example COD of $\mathrm{C} 2$ (Fig.9a), $\mathrm{S}_{1}$ in influent was about $26 \mathrm{mg} / \mathrm{L}$ and the initial COD in settler was $36 \mathrm{mg} / \mathrm{L}$. So about $10 \mathrm{mg} / \mathrm{L}$ COD was available for denitrification and about $1.3 \mathrm{mg} / \mathrm{L}$ $\mathrm{NO}_{3}-\mathrm{N}$ would be transformed. Unfortunately, the $\mathrm{NO}_{3}-\mathrm{N}$ would not be transformed completely lacking of sufficient COD supply. After $30 \mathrm{~min}$, the COD supply from Tank $\mathrm{B}$ reduced, so transformed $\mathrm{NO}_{3}-\mathrm{N}$ reduced, leading to increasing $\mathrm{NO}_{3}-\mathrm{N}$ in effluent.

Since the bio-chemical activity was going on in settler, the sludge would undertake endogenous respiration because of insufficient COD supply. As a result, the $\mathrm{NH}_{3}-\mathrm{N}$ could be released (Henze et al., 1987, 1995, 1999), which might make $\mathrm{NH}_{3}-\mathrm{N}$ increasing in effluent. Fig.9b shows
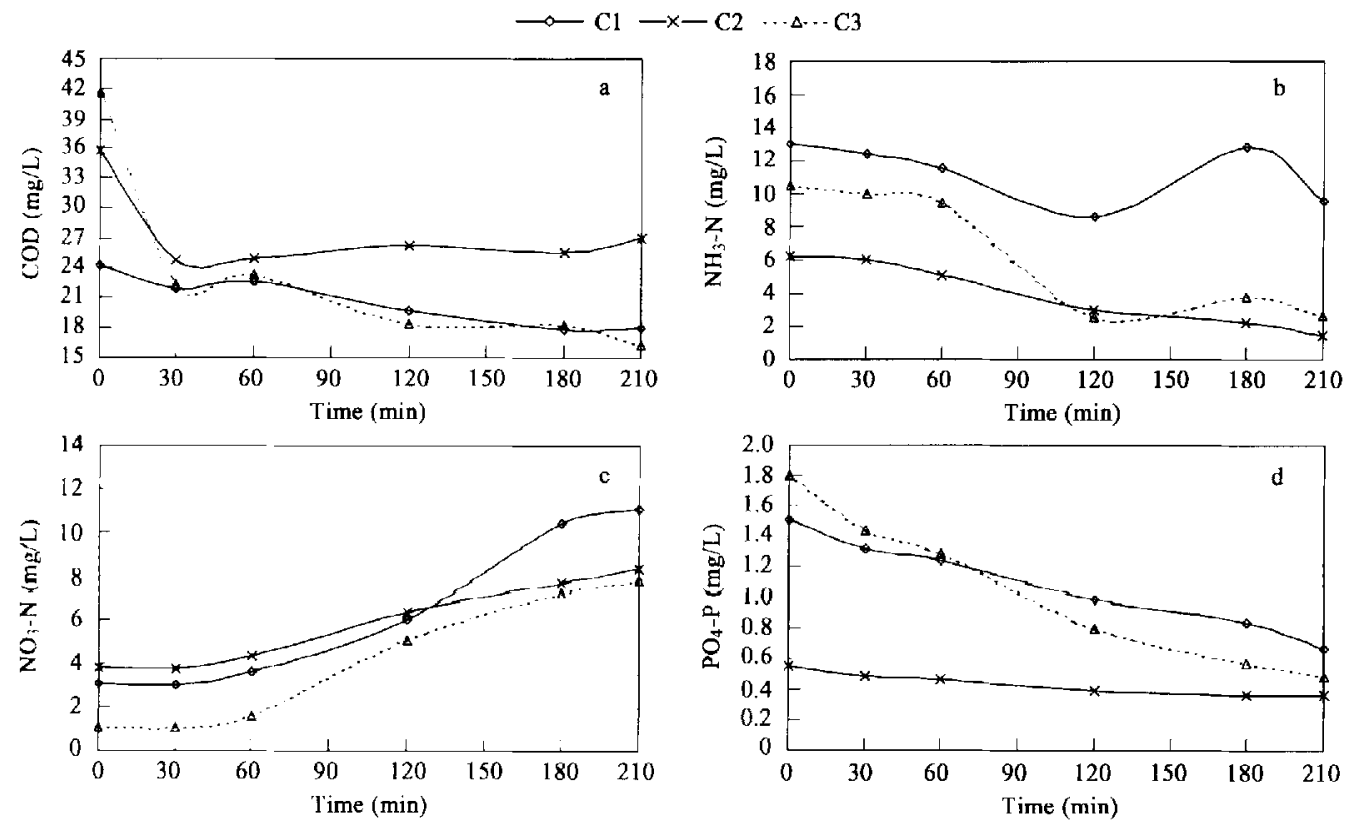

Fig. 9 Variation of $\mathrm{COD}$ (a), $\mathrm{NH}_{3}-\mathrm{N}$ (b), $\mathrm{NO}_{3}-\mathrm{N}$ (c) and $\mathrm{PO}_{4}-\mathrm{P}$ (d) in effluent. 


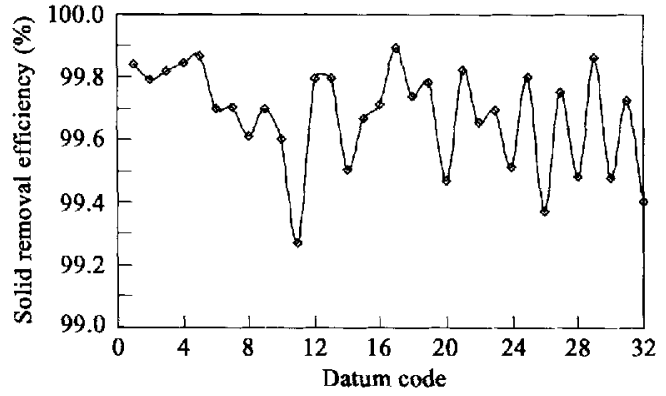

Fig. 10 Settler's characteristic of UNITANK.

that the $\mathrm{NH}_{3}-\mathrm{N}$ changed unsteadily, which is different from that in Fig.8b. It indicated that the too high sludge concentration is bad for $\mathrm{NH}_{3}-\mathrm{N}$ removal but long SRT and comparatively lower sludge concentration help to remove $\mathrm{NH}_{3}-\mathrm{N}$ (Table 6 and Fig.9b).

It is still difficult to describe what happened on $\mathrm{PO}_{4}$-P. In $\mathrm{C} 3$, the $\mathrm{PO}_{4}-\mathrm{P}$ decreased from 1.8 to $0.6 \mathrm{mg} / \mathrm{L}$ and in $\mathrm{C} 2$, $\mathrm{PO}_{4}-\mathrm{P}$ was between 0.4 and $0.6 \mathrm{mg} / \mathrm{L}$ (Fig.9d). But the high sludge concentration might release more $\mathrm{PO}_{4}-\mathrm{P}$ into effluent (C1 and $\mathrm{C} 2$ in Fig.9d). Some explanations refer to 2.4.1.

\section{Conclusions}

The sludge distributions in Tank A and B are correspondent. Given the initial sludge concentration in Tank A, the sludge distributions in reactors could be described. The sludge distribution in reactors is mainly influenced by hydraulic condition. The HRT and lengths of half-cycle and feeding period should be well controlled.

The performance of UNITANK is influenced strongly by sludge distribution. Unsteady sludge concentration leads to the variations of substrates. Especially in decisive reactor, the conditions of sludge concentration and oxygen should be strictly controlled. Steady sludge concentration and aerobic situation are very important.

In settler, part $\mathrm{COD}$ and $\mathrm{NO}_{3}-\mathrm{N}$ could be removed by denitrification, but there is adventure of sludge floating. Furthermore, the accumulated sludge in settler may release some substrate such as $\mathrm{NH}_{3}-\mathrm{N}$, so the sludge concentration should be rational. The initial sludge concentration in Tank A should be $4000-6000 \mathrm{mg} / \mathrm{L}$ MLSS.

Long SRT helps to remove $\mathrm{NH}_{3}-\mathrm{N}$. UNITANK is potential to remove $\mathrm{PO}_{4}-\mathrm{P}$ but the mechanism should be studied further.

\section{References}

Adeline S M C, Hiroo T, Hiroyasu S et al,, 2003. Production of polyhydroxyalkanoates (PHA) by activated sludge treating municipal wastewater: effect of $\mathrm{pH}$, sludge retention time (SRT), and acetate concentration in influent[J]. Water Res, 37: 3602-3611.

Barker P S, Dold P L, 1997. General model for biological nutrient removal activated sludge system: model presentation[J]. Water Environ Res, 69: 969-984.

Brdjanovic D, van Loosdrecht M C M, Versteeg P et al., 2000.
Modelling COD, $\mathrm{N}$ and $\mathrm{P}$ removal in a full-scale WWTP Haarlem Waarderpolder[J]. Water Res, 34: 846-858.

Carstensen J, Nielsen M K, Strandbak H, 1998. Prediction of hydraulic load for urban storm control of a municipal WWT plant[J]. Water Sci Technol, 37(12): 363-370.

Chang K Y, Peter A V, Lee I B, 2003. Nonlinear modeling and adaptive monitoring with fuzzy and multivariate statistical methods in biological wastewater treatment plants[J]. Biotechnology, 105(1/2): 135-163.

Clara M, Kreuzinger N, Strenn B et al., 2005.The solids retention time-a suitable design parameter to evaluate the capacity of wastewater treatment plants to remove micropollutants[J]. Water Res, 39(1): 97-106.

Hasselblad S, Björlenius B, Carlsson B, 1998. Use of dynamic models to study secondary clarifier performance[J]. Water Sci Technol, 37(12): 207-212.

Henze M, Grady C P L, Gujer Jr et al., 1987. Activated sludge model No.1[R]. IAWPRC Scientific and Technical Report No.1, London, UK.

Henze M, Gujer W, Mino T et al., 1995. Activated sludge model No.2[R]. IWAQ Scientific and Technical Report No.3, London, UK.

Henze M, Gujer W, Mino T et al., 1995. Wastewater and biomass characterization for the activated sludge model No.2: Biological phosphorus removal[J]. Water Sci Technol, 31(2): $13-23$.

Henze M, Gujer W, Mino T et al., 1999. Activated sludge model No.2D, ASM2D[J]. Water Sci Technol, 39(1): 165-182.

Henze M, Aspegren H, Cour $\mathrm{J}$ et al., 2002. Effect of solids retention time and wastewater characteristic on biological phosphorus removal[J]. Water Sci Technol, 45(6): 137-144.

Kazmi A A, Furumai H, 2000. A simple model for batch activated sludge process[J]. Water Sci Technol, 42(3/4): 9-16.

Leslie G C P, Glen Jr, Daigger T et al., 1999. Biological wastewater treatment[M]. 2nd ed. New York: Marcel Dekker, Inc.

Ligero P, de Vega A, Soto M, 2001. Influence of HRT (hydraulic retention time) and SRT (solid retention time) on the hydrolytic pre-treatment of urban wastewater[J]. Water Sci Technol, 44(4): 7-14.

Liss N S, Liao B Q, Droppo I G et al., 2002. Effect of solids retention time on floc structure[J]. Water Sci Technol, 46(1/2): 431-438.

Wong M T, Mino T, Seviour R J et al., 2005. In situ identification and characterization of the microbial community structure of full-scale enhanced biological phosphorous removal plants in Japan[J]. Water Research, 39(13): 2901-2914.

Peter K, 1998. Short SRT (solids retention time) nitrification process/flowsheet[J]. Water Sci Technol, 38(1): 23-29.

Rieger L, Koch G, Kühni M et al., 2001. The EAWAG bio$P$ module for activated sludge model No.3[J]. Water Res, 35(16): 3887-3903.

Roelveld P J, van Loosdrecht M C M, 2002. Experience with guidelines for wastewater characterization in the Netherlands[J]. Water SciTechnol, 45(6): 77-87.

Siegrist H, Gujer W, 1994. Nitrogen removal in activated sludge system including denitrification in secondary clarifiers $[J]$. Water Sci Technol, 30(6): 101-111.

Standard methods for the examination of water and wastewater[S], 1995. 19th ed. Washington DC, USA: American Public Health Association/American Water Works Association/Water Environment Federation.

Yoshitaka Matsuo, 1994. Effect of the anaerobic solids retention time on enhanced biological phosphorus removal[J]. Water Sci Technol, 30(6): 193-202. 